\title{
Eshing Ekai Thabi - An Underutilised Aquatic Vegetable of Manipur
}

\author{
Supriya Yenkokpam ${ }^{1}$ and Y. Ranjana Devi ${ }^{2 *}$ \\ ${ }^{1}$ Assam Agricultural University, Jorhat, Assam, India \\ ${ }^{2}$ Central Agricultural University, Lamphelpat, Imphal, India
}

*Corresponding author

\section{A B S T R A C T}

\section{Keywords \\ Eshing Ekai Thabi, Water mimosa, Underutilised vegetable, \\ Phytoremediation, Green manure \\ Article Info \\ Accepted: \\ 10 September 2018 \\ Available Online: \\ 10 October 2018}

Water mimosa, a pantropical nitrogen-fixing perennial legume, locally known as Eshing Ekai Thabi is an important aquatic vegetable of Manipur. The present study was carried out to document the mode of use and importance of the plant. It was observed that the plant is used as a culinary delicacy and also for its nutritional and medicinal properties. This underutilized vegetable is embedded with rich nutrient potentials along with ability to stand against adverse climatic conditions. The cultivation of this aquatic vegetable has helped to sustain the livelihood of community around the waste water wetland where it is grown. Awareness about the multifaceted use of the plant as organic manure and for phytoremediation for polluted waters may be created so that water mimosa may be uplifted from being an underutilised vegetable to an economically important vegetable crop.

\section{Introduction}

Neptuniaoleracea Lour. locally known as Eshing Ekaithabi and commonly known as water sensitive plant or water mimosa, is a wild aquatic legume native to several continents of the humid tropics of both hemispheres particularly in Asia, Africa and South America (Windler, 1966; Gen and Eiji, 1974). It is cultivated as vegetable throughout Southeast Asia, particularly in Indo-China and Thailand (Paisooksantivatana, 1993). The north eastern region of India provides favourable condition for growth and propagation of the plant owing to its ample rainfall, humidity and moderate range of temperature (Sinha, 1996; Majumdar and
Dutta, 2007; Sarma and Monjit, 2010). Neptuniaoleracea Lour. grows on the banks or margins of water bodies and then spreads out over the water surface (Bhunia and Mondal, 2012; Csurhes, 2016). It prefers lakes, farm dams, ponds and swamps but also grows along slow moving water ways. The stems are terete, rarely branched and detached from the primary root system. It forms white spongy fibrous swollen internodes and produce clustered brown fibrous adventitious roots at the nodes when growing in water. The white spongy tissue helps the plant to float in the water. The leaves are bi-pinnate with 2-4 pairs of pinnae with hairless leaflets. Flowers are bright yellow in colour and have very long peduncles in sub spherical axillary heads. The 
pods are shortly oblong in umbel like cluster, green in colour. It has an unusual smell that can be used in the identification of the plant. It can be grown via seeds or can be propagated through cuttings. The plant is found abundantly during the rainy season. When the water level falls during the dry season, the plants often perish.

Meitei, the valley inhabitants of the state of Manipur have the tradition of eating raw plants, the knowledge of which is handed over from generation to generation through the belief that they get direct nutritional and medicinal benefit by this mode of eating (Yumnam and Tripathi, 2012). Eshing Ekai Thabi is found cultivated in the ponds and wetlands in valley areas of Imphal, Manipur. It is sold in the markets during its season (June-August) in bundles of 4-5 plants of about 10-15 inches length and costs around 20-30 rupees each. Considering that very less literature is found about Eshing Ekai Thabi in the ethnobotanical studies of Manipur, the present study was carried out to document the mode of use and importance of theaquatic vegetable crop of Manipur.

\section{Materials and Methods}

For documentation of the traditional method of consumption of Eshingekaithabi, a survey was carried out in villages of valley areas of Manipur. Informants were of Meitei community in Imphal East, West, Bishenpur and Thoubal district of Manipur and were mostly elderlyfolk aged over 40 years old who has thorough knowledge about the use of the plant. Local healers and practitioners (locally known as Maibas) were also consulted with regard to the medicinal use of the plant.

\section{Results and Discussion}

During the survey, it was observed that there are different modes of use of Eshingekaithabi.
It is eaten as a vegetable or used for its medicinal properties. The young leaves, shoot tips, ends of stem and young pods are usually eaten raw or in stir-fries.

For medicinal benefits, the plant is either consumed fresh or as decoction or for local application and is mainly used for treatment of:

Nose bleeding: The pounded leaves and stem of the plant is applied over the nose to treat syphilitic ulcers/necrosis of the nose

Dysentery and Intestinal Infection: The leaf of the plant is eaten raw to treat dysentery and intestinal infection. Alternatively, decoction is prepared by crushing the leaves of the plant with water and given to the person twice a day (morning and evening) until cured.

Anthelminthic: Decoction is prepared by crushing the leaves of the plant with water and given to the person twice a day (morning and evening) for three days to treat parasitic worm infections.

Earache: The juice of the stem and leaf is squeezed into the ear to cure earache

Water Mimosa has been consumed by people from Malaysia, Thailand and Cambodia due to its nutritional values. The edible portion of the shoot is found to contain (per 100g): Moisture-89.4 g; Protein-6.4 g; Fat-0.4 g; Carbohydrates-0.8 g; Fibre-1.8 g; Ash-1.2 g; Ca-887 mg; P-7 mg; Fe-5.3 mg; Vitamin A$5155 \mathrm{IU}$; Vitamin $\mathrm{B}_{1}-0.12 \mathrm{mg}$; Vitamin $\mathrm{B}_{2^{-}}$ $0.14 \mathrm{mg}$, Niacin-8.2 mg; Vitamin C-1.8 mg and the energy value of the plant is $184 \mathrm{Kj} / 100 \mathrm{~g}$ (Csurhes, 2016).Several authors (Chanwitheesuk et al., 2005; Abulude, 2005, Prusty et al., 2007; Noorasmah et al., 2015) have reported the presence of $\mathrm{Na}, \mathrm{K}, \mathrm{Ca}, \mathrm{Mg}$, $\mathrm{K}, \mathrm{Mn}, \mathrm{Cu}, \mathrm{Zn}, \mathrm{Fe}, \mathrm{P}, \mathrm{Pd}$ and $\mathrm{Ni}$ in varying concentrations. 


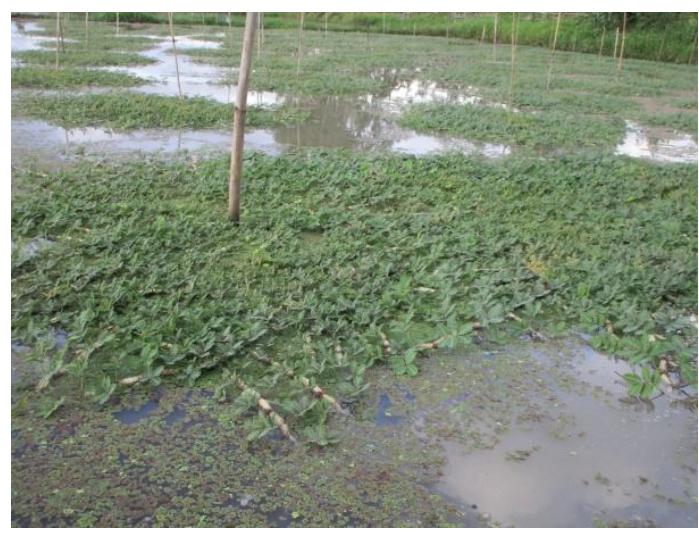

Fig.1 Cultivation of Eshing Ekai Thabi in farmers pond in Imphal, Manipur

A recent study (Islam et al., 2018) found that the in vitro total antioxidant capacity (TAC) of Eshing Ekai Thabi (Neptuniaoleracea) was found to be the highest (IC50 $\mu \mathrm{g} / \mathrm{mL}$ : $428 \pm$ 5.79 and $403 \pm 2.25$ in stems and leaves, respectively), followed by Toning Khok (Houttuyniacordata) and Mayang Ton (Ocimumcanum) of herb, spices and aromatic plant origin (IC50 $\mu \mathrm{g} / \mathrm{mL}$ : $513 \pm 5.66$ and 744 \pm 23.90 , respectively).

The use of the pounded plant by applying over the nose to treat syphilitic ulcers/necrosis of the nose and hard palate and for treating advanced stage of syphilis in different south East Asian countries has been reported by number of authors (Chopra et al., 1986; Nakamura et al., 1996; Ong, 2008; Ita, 1994).

Similarly, use of the plant for treatment of dysentery and intestinal infection and to cure earache has been reported from Malaysia (Paisooksantivatana, 1993). The plant is also used for treatment of fever by applying the infusion of the whole plant on the body of the patient and is also used for treatment of yellow fever and Guinea worm infection in Nigeria (Ita, 1994). Reports on use of Neptuniaoleracea for treatment of sores on tongue, white discharge and epilepsy has been documented (Singh et al., 2015) however, the present survey does not find its use for the three ailments in the Meitei community.

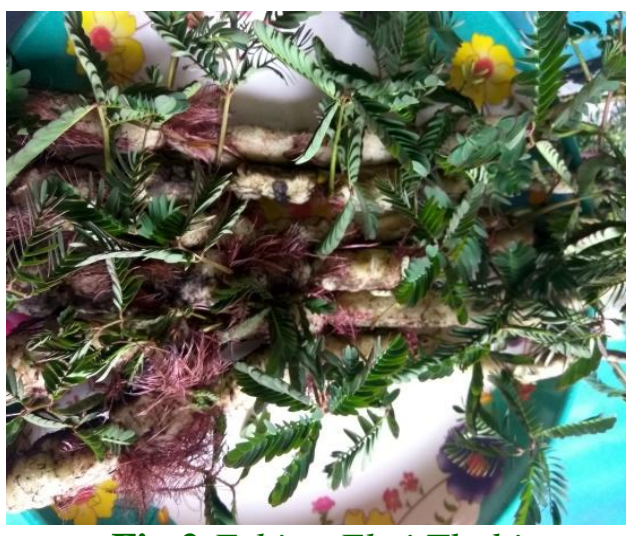

Fig.2 Eshing Ekai Thabi

(Neptuniaoleracea Lour)

The mimosoid legume genus Neptunia has attracted much interest in the last 15 years, largely because of the aquatic habitat to some of its species and the ability of some of these to form $\mathrm{N}_{2}$ fixing root nodules on submerged roots (James, 1992a; James, 1992b; Rao et al., 1995).

The use of nodulated wetlands legumes as green manures in the cultivation of lowland rice due to their high ratio of $\mathrm{N}_{2}$ fixation under flooded conditions has been reported so it is cultivated in Asian countries for green manures for rice cultivation (Dreyfus et al., 1985; Morris et al., 1989; Ladha et al., 1992). The plant is being used as phytoremediation to treat waste and polluted water (Suppadit et $a l .$, 2005). It was also demonstrated that water mimosa could be used to remediate waste water polluted with $\mathrm{Cd}, \mathrm{Cu}$ and $\mathrm{Pb}$ (Wahab et al., 2014).

However certain disadvantages are also associated with the plant as this nitrogenfixing legume releases nitrogen into water bodies leading to increased algal blooms and encourage growth of other weeds such as water hyacinth, water lettuce and salvinia (Csurhes, 2016). Excess nitrogen affects water quality and increases water-treatment costs hence, it is declared as a restricted invasive plant under the Biosecurity Act 2014 in the State of Queensland (Csurhes, 2016). 
Based on the documented multipurpose use of the plant, it can be concluded that Eshing Ekai Thabi is an underutilized aquatic vegetable which is embedded with rich nutrient potentials along with ability to stand against adverse climatic conditions. Due to its high nutritional and medicinal properties, the plant plays an important role against malnutrition in the weaker section of the society. The plant may be used as phytoremediation to treat waste and polluted water. The possible reasons for the low utilization of the vegetable in spite of their recognized importance may be the lack of information about their performance, hence, an awareness needs to be created so that the cultivation of the plant may prove to be a boon to all concerned i.e. the growers, consumers and environmentalists, provided that they are tamed properly.

\section{Acknowledgement}

The authors are very much thankful to the indigenous Meitei community Imphal East, West, Bishenpur and Thoubal Districts of Manipur for their cooperation, active participation and sharing of valuable information during the course of study.

\section{References}

Abulude, F.O. (2005). Nutritional evaluation of aquatic weeds in Nigeria. Electronic Journal of Environmental, Agricultural and Food Chemistry. 4(1): 835-840.

Bhunia Debasis and Mondal Amal Kumar. 2012. Sytematic analysis (Morphology, Anatomy and Palynology) of an aquatic medicinal plant water mimosa (Neptunia oleracea Lour.) in Eastern India. International J. Life Science Biotechnology \& Pharm. Res. 1 (2): 290319.

Chanwitheesuk, A., Teerawutgulrag, A. and Rakaiyatham, N. 2005. Screening of antioxidant activity and antioxidant compounds of some edible plants of Thailand. Food Chemistry. 92: 491-497.
Chopra, I.C., Khajuria, B.N., Chopra, C.L. 1986. Antibacterial Principles of Alpinia Galangal and Acoruscalamus. Antibiotics Chemother. 7: 378.

Csurhes, Steve. 2016. Invasive plant risk assessment- Water Mimosa (Neptunia oleracea); Dead and Awake (Neptunia plena). Department of Agriculture and Fisheries, Biosecurity Queensland, Queensland government, State of Queensland: 1-13

Dreyfus, B., Rinaudo, G. and Dommergues, Y.R. 1985. Observation on the use of Sesbania rostrata as green manure in paddy fields. Mireen Journal. 1: 111-121.

Gen, M. and Eiji, M.I. 1974. Natural Vegetation and Physiography of the Central Plain of Thailand. Southeast Asian Studies. 12 (3): 280-290.

Islam, G.M. \&AkterSyeda and Hoque, Md. 2018. Traditional foods for health: in vitro screening for antioxidant capacity of popular traditional tribal foods in the Sylhetterritory in Bangladesh-focusing on total phenolic and tannin contents. Journal of Food Measurement and Characterization. 10.1007/s11694-0189823-3.

Ita, E.O. 1994. Aquatic plants and wetland wildlife resources of Nigeria, CIFA Occasional Paper. No. 21, Rome, FAO. Pp 52

James, E.K., Minchin, F.R. and Sprent, J.I. 1992 a. The Physiology and Nitrogenfixing capability of Aquatic and Terrestrially grown Neptunia Plena: The Importance of Nodule Oxygen Supply. Ann. Bot. 69:181-187.

James, E.K., Sprent, J.I., Sutherland, J.M., McInroy, S.G. and Minchin, F.R. 1992 b. The structure of nitrogen fixing root nodules on the aquatic mimosoid legume Neptunia plena. Annals of Botany. 69: 173-180.

Ladha, J.K., Pareek, R.P. and Becker, M. 1992. Stem-nodulating legume-Rhizobium symbiosis and its agronomic use in lowland rice. Advance in Soil Science. 20: 148-192. 
Majumdar, K. and Dutta, B.K. 2007. A study on ethnomedicinal usage of plants among the folklore herbalists and Tripuri medical practitioners: Part II, Natural Product Radiance. 6(1): 66-73.

Morris, R.A., Furoc, R.E., Rajbhandri, N.K., Marqueses, E.P. and Dizon, M.A.1989. Rice response to waterlog tolerant green manures. Agronomy Journal. 81: 803809.

Nadkarni, K.M.2005. Dr. K.M. Nadkarni's Indian MeteriaMedica; Repr. Vol 1, Popular Prakashan Pvt. Ltd, Mumbai. Pp 847.

Nakamura, Y., Murakami. A., Koshimuzu, K. and Ohigashi, H., 1996. Identification of pheophorbidea and its related compounds as possible anti-cancer promoters in the leaves of Neptunia Oleracea. Biosci. Biotech. Biochem. 60(6): 1028-1030.

Noorasmah, S., Muta H. Z., Japar S. B. and Arshad A., 2015. The proximate compositions and mineral contents of Neptunia oleracea Loureiro, An aquatic plant from Malaysia. Emir J Food Agric. 27(3): 266-274.

Ong Hean Chooi, 2008. Vegetables For Health And Healing. Utusan Publications, Kuala Lumpur. Pp. 187

Paisooksantivatana, Y., Neptuniaoleracea Loureiro - Plant Resources of South-East Asia No. 8: Vegetables, JS Siemonsma \& K. Piluek (eds), (1993) 217-18, Pudoc, Wageningen, Netherlands.

Prusty, B.A.K., Azeez, P.A. and Jagadeesh, E.P. 2007. Alkali and Transition Metals in Macrophytes of a Wetland System. Bull. Environ Contam Toxicol. 78: 405-410.
Sarma, S.K. and Saikai, M. 2010. Utilization of wetland resources by the rural people of Nagaon district, Assam. Indian Journal of traditional Knowledge. 9(1):145-151.

Singh, V., Shah, N.K.H. and Rana, D.K. 2015. Medicinal importance of unexploited vegetables under North Eastern Regions of India. Journal of Medicinal Plants Studies. 3(3): 33-36

Sinha, S.C.1996. Medicinal plants of Manipur, Mass and Sinha, Imphal, pp. 124.

SubhaRao N.S., Mateos, P.F., Baker, D., Pankrazt, H., Palma, J. et al., 1995. The unique root-nodule symbiosis between Rhizobium and the aquatic legume Neptunianatans (1.f) Druce. Planta. 196: 311-320.

Suppadit, T., Phoochinda, W. and Bunsinchai, P. 2005. Treatment of effluent from shrimp farm by using water mimosa (Neptunia olereceae Lour.). J. Int. Soc. Southeast Asian Agri Sci. 11(2):1-11.

Wahab, A.S.A., Ismail, S.N.S., Praveena, S. M., Awang, S.2014. Heavy Metals Uptake of Water Mimosa (Neptunia oleracea) and Its Safety for Human Consumption. Iraman J Publ Health. 43 (3):103-111.

Windler, D.R. 1966. A revision of the Genus Neptunia (Leguminosae). Australian Journal of Botany. 14: 379-420.

Yumnam, J.Y. and Tripathi, O.P. 2012. Traditional knowledge of eating raw plants by the Meiteis of Manipur as medicine/nutrient supplement in their diet. Indian Journal of Traditional Knowledge. 11(1): 45-50

\section{How to cite this article:}

Supriya Yenkokpam and Ranjana Devi, Y. 2018. Eshing Ekai Thabi - An Underutilised Aquatic Vegetable of Manipur. Int.J.Curr.Microbiol.App.Sci. 7(10): 1292-1296. doi: https://doi.org/10.20546/ijcmas.2018.710.145 